\title{
Synthesis of PES and PES/chitosan membranes for synthetic acid mine drainage treatment
}

\author{
Mathaba J Machodi' and Michael O Daramola' \\ 'School of Chemical and Metallurgical Engineering, Faculty of Engineering and the Built Environment, University of the Witwatersrand, \\ Private Bag X3, Wits 2050, Johannesburg, South Africa
}

In this study, chitosan was synthesised from chitin and used to modify polyethersulphone (PES) membrane prepared by the phase inversion method. PES membrane was blended with various concentrations of chitosan to produce PES $/ 0.5 \mathrm{wt} \%$ chitosan, $\mathrm{PES} / 0.75 \mathrm{wt} \%$ chitosan and PES $/ 1 \mathrm{wt} \%$ chitosan membranes. The membranes were tested for metal and sulphate removal from acid mine drainage (AMD). The fabricated membranes were characterised using scanning electron microscopy (SEM), contact angle analyser, Fourier transform infrared (FTIR), porosity determination and pure water flux measurements. Separation performance was conducted on a dead-end filtration cell and metal ions were determined by atomic absorption spectroscopy (AAS), and ultraviolet and visible (UV-vis) spectrophotometry was used for sulphates. Pure water flux of the pristine PES membrane increased from $102 \mathrm{~L} \cdot \mathrm{m}^{-2} \cdot \mathrm{h}^{-1}$ to $107 \mathrm{~L} \cdot \mathrm{m}^{-2} \cdot \mathrm{h}^{-1}$ and $133 \mathrm{~L} \cdot \mathrm{m}^{-2} \cdot \mathrm{h}^{-1}$ for PES/0.5 wt $\%$ and PES/0.75 $\mathrm{wt} \%$, respectively. Further addition of chitosan to $1 \mathrm{wt} \%$ created a dense structure on the membrane surface, thereby reducing the flux to $120 \mathrm{~L} \cdot \mathrm{m}^{-2} \cdot \mathrm{h}^{-1}$. The rejection of cations and sulphate ions significantly improved for chitosan-modified membranes due to the creation of adsorptive and/or repulsive sites on the chitosan biopolymer as a result of amine group protonation. The results reveal that chitosan has potential to improve performance of PES membranes as a hydrophilic agent during AMD treatment.

\section{INTRODUCTION}

The discharge of acidic wastewater from active and abandoned mines poses significant water quality and environmental problems globally (Larsson et al., 2018). During mining operations, sulphidecontaining rocks such as pyrites $\left(\mathrm{FeS}_{2}\right)$ get exposed to water, air and microbial activities, which makes them vulnerable to oxidation. Pyrite will react with oxygen and water to produce acidic discharge which acts as a leaching agent of toxic metals and trace elements available in the host rocks (Kefeni et al., 2018). Equations 1 to 4 show the formation of acid drainage in the presence of air (oxygen), water and bacteria (Bwapwa et al., 2017; Othman et al., 2017; Kaur et al., 2018). The pyrite $\left(\mathrm{FeS}_{2}\right)$ oxidation releases hydrogen, sulphate and ferrous irons $\left(\mathrm{Fe}^{2+}\right)$ (Eq. 1). Further oxidation of ferrous iron $\left(\mathrm{Fe}^{2+}\right)$ releases ferric iron $\left(\mathrm{Fe}^{3+}\right)$ (Eq. 2) which either acts as an oxidizing agent and oxidizes more pyrite (Eq. 3) or will precipitate as iron hydroxide $\left(\mathrm{Fe}(\mathrm{OH})_{3}\right)$ (Eq. 4).

$$
\begin{aligned}
& 2 \mathrm{FeS}_{2(s)}+2 \mathrm{H}_{2} \mathrm{O}_{(l)}+7 \mathrm{O}_{(g)} \rightarrow 2 \mathrm{Fe}^{2+}{ }_{(a q)}+4 \mathrm{SO}_{4}{ }^{2-}{ }_{(a q)}+4 \mathrm{H}^{+}{ }_{(a q)} \\
& 2 \mathrm{Fe}^{+}{ }_{(a q)}+2 \mathrm{H}^{+}{ }_{(a q)}+1 / 2 \mathrm{O}_{2(g)} \rightarrow 2 \mathrm{Fe}^{3+}{ }_{(a q)}+2 \mathrm{H}_{2} \mathrm{O}_{(l)} \\
& \left.\mathrm{FeS}_{2(s)}+14 \mathrm{Fe}^{3+}{ }_{(a q)}\right)+8 \mathrm{H}_{2} \mathrm{O}_{(l)} \rightarrow 15 \mathrm{Fe}^{2+}{ }_{(a q)}+2 \mathrm{SO}_{4}^{2-}{ }_{(a q)}+16 \mathrm{H}^{+}{ }_{(a q)} \\
& \mathrm{Fe}^{3+}{ }_{(a q)}+3 \mathrm{H}_{2} \mathrm{O}_{(l)} \rightarrow \mathrm{Fe}(\mathrm{OH})_{3(s)}+3 \mathrm{H}^{+}{ }_{(a q)}
\end{aligned}
$$

Membrane separation process (MSP) has been successfully applied to treat AMD due to the high salt and metal retention capacity of membranes (Ritchie and Bhattacharyya, 2002; Geise et al., 2010; Elimelech and Phillip, 2011; Daramola et al., 2015). Nanofiltration (NF) membrane is the most preferred because of its low required pressure and energy consumption, high selectivity and permeate flux. NF membranes which are intermediate membranes between ultrafiltration (UF) and reverse osmosis (RO) membranes have higher permitted flux compared to other pressure-driven membranes and can retain dissolved molecules with molecular weight greater than 200 to $300 \mathrm{~g} \cdot \mathrm{mol}^{-1}$, as well as inorganic ions through electrostatic interaction between membrane charge and the ions combined with size exclusion (Carvalho et al., 2011). Astudy by Aguiar et al. (2016) showed NF membranes to be more suitable for AMD treatment than RO which had high permeate flux and solute rejection. Most commercial NF membranes available in the market are constructed using polyethersulphone (PES) material prepared through phase inversion methods (Zhao et al., 2013).

A significant challenge confronting NF membrane application is fouling, which is caused by suspended or dissolved organic and/or inorganic matter migrating from the liquid phase and forming deposits on the membrane surface, at the pore openings or within the membrane matrix (Aguiar et al., 2016). For economically feasible operation, membrane fouling must be controlled since it reduces permeability, increases energy consumption and shortens membrane lifespan. Although membrane fouling is considered inevitable, the rate and extent is highly impacted by membrane properties, feed characteristics and operational conditions (Wei et al., 2010). Although PES and PES-based membranes have been widely used, the main disadvantage is related to its

\section{CORRESPONDENCE}

Michael O Daramola

\section{EMAIL}

Michael.Daramola@wits.ac.za

\section{DATES}

Received: 14 March 2019

Accepted: 13 November 2019

\section{KEYWORDS}

polyethersulphone acid mine drainage chitin

membrane flux

\section{COPYRIGHT}

(c) The Author(s)

Published under a Creative Commons Attribution 4.0 International Licence (CC BY 4.0) 
hydrophobic character (Zhao et al., 2013). Several studies reviewed by Van der Bruggen (2009) and Khulbe et al. (2010) indicate that hydrophobicity is directly related to fouling. Introducing materials with high anti-fouling properties improves performance of pure polymeric membranes. Addition of hydrophilic functional groups through common practices such as surface grafting (Rahimpour, 2011), coating (Reddy et al., 2003) or blending with hydrophilic polymers (Peyravi et al., 2012) or nanoparticles (Vatanpour et al., 2012; Ji et al., 2015) has been widely reported to modify polymeric membranes. A large number of amino $\left(-\mathrm{NH}_{2}\right)$ and hydroxyl groups which can act as binding sites for contaminants, and additional features such as high hydrophilicity, high mechanical and chemical stability and charge density, make chitosan a suitable membrane modifier (Wan Ngaha et al., 2011). The reactive amino functional groups on the chitosan structure binds to almost all Group III and transition metals. In acidic medium, the amino group gets protonated and attracts metal anions through ion exchange and repels cations through electrostatic repulsion (Anirudhan and Rijith, 2012).

Despite the research efforts on the use of modifiers in membrane modification, application of chitosan as a membrane modifier for the treatment of AMD is not well studied. Therefore, the aim of this study was to synthesize polyethersulphone membranes modified with chitosan for AMD treatment.

\section{METHODS}

\section{Materials}

Dimethyl sulfoxide (DMSO), polyethersulphone (PES) granules $(3 \mathrm{~mm})$, sodium hydroxide $(\mathrm{NaOH})$, sulphuric acid $\left(\mathrm{H}_{2} \mathrm{SO}_{4}\right)$ and metal sulphate salts were purchased from SigmaAldrich (Pty) Ltd, South Africa. The chemicals were analytical grade, and therefore were used without further purification. Deionized water was prepared in-house and had a $\mathrm{pH}$ of 6.89 and conductivity of $0.19 \mathrm{mS} \cdot \mathrm{cm}^{-1}$. The $\mathrm{pH}$ and conductivity were measured using a Metler Toledo dual meter (Sevenduo $\mathrm{pH} /$ conductivity meter with a Metler Toledo inLab Pro ISM $\mathrm{pH}$ electrode and inLab 738 ISM conductivity probe). Chitosan used in this study was synthesized from chitin that was obtained by processing seashells collected from Durban South Beach, Rutherford.

\section{Model AMD}

Synthetic AMD solution (Table 1) was prepared as per the characterized data obtained from Tutu et al. (2008) and the composition of mine-water collected from Randfontein (Black Reef Incline, 17 and 18 Winzes). Synthetic AMD solution was used to avoid competition between desired and undesired species present in real AMD. The AMD was prepared in $1000 \mathrm{~mL}$ of water and the $\mathrm{pH}$ was adjusted with concentrated sulphuric acid to 3.2.

\section{Production of chitosan and synthesis of membrane}

Firstly, seashells were washed and boiled in water to remove any impurities before crushing and milled with milling rods into fine powder (chitin). The following steps were carried out in chronological order to extract chitosan from milled chitin powder, (i) deproteinization, (ii) demineralization and (iii) deacetylation. Deproteinization was carried out by treating chitin with $6 \% \mathrm{NaOH}$ solution and demineralization using $6 \% \mathrm{HCl}$. The steps were carried out for $2 \mathrm{~h}$ at $60^{\circ} \mathrm{C}$ on a heating plate equipped with a magnetic stirrer. The resulting chitin was filtered with a vacuum pump and washed with deionized water until neutral $\mathrm{pH}$. Deacetylation was carried out with $40 \% \mathrm{NaOH}$ at $120^{\circ} \mathrm{C}$ for $2 \mathrm{~h}$. The deacetylated chitosan was washed with
Table 1. Composition of the synthetic AMD

\begin{tabular}{lcc}
\hline Salt dissolved & Species & $\begin{array}{c}\text { Concentration }\left(\mathrm{mg} \cdot \mathrm{L}^{-1}\right) \\
\mathrm{pH}=3.2\end{array}$ \\
\hline $\mathrm{FeSO}_{4} \cdot 7 \mathrm{H}_{2} \mathrm{O}$ & $\mathrm{Fe}^{2+}$ & 933 \\
$\mathrm{CaSO}_{4} \cdot 2 \mathrm{H}_{2} \mathrm{O}$ & $\mathrm{Ca}^{2+}$ & 461 \\
$\mathrm{MgSO}_{4} \cdot 7 \mathrm{H}_{2} \mathrm{O}$ & $\mathrm{Mg}^{2+}$ & 345 \\
$\mathrm{MnSO}_{4} \cdot \mathrm{H}_{2} \mathrm{O}$ & $\mathrm{Mn}^{2+}$ & 321 \\
$\mathrm{Na}_{2} \mathrm{SO}_{4}$ & $\mathrm{SO}_{4}{ }^{2-}$ & 4556 \\
\hline
\end{tabular}

deionized water until neutral $\mathrm{pH}$. The solid to liquid ratio for all processes was set at 1:20.

\section{PES and modified PES membrane preparation}

PES granules were dissolved in DMSO on a magnetic stirrer at room temperature measured at $26.8{ }^{\circ} \mathrm{C}$. Chitosan was added at different concentrations $(0,0.5,0.75$ and $1 \mathrm{wt} \%)$ and stirred for $24 \mathrm{~h}$ to obtain a homogenous gel. Before casting, the casting solution was left at ambient conditions to remove any air bubbles for $24 \mathrm{~h}$. The gel was cast on a glass plate with a casting knife at $250 \mu \mathrm{m}$ thickness. The membranes were immersed in deionized water and left in a coagulation bath for $24 \mathrm{~h}$ to allow desorption of the solvent from the membrane. The membranes were heated in an oven at $60^{\circ} \mathrm{C}$ to evaporate any trapped water and/or solvent from the membrane.

\section{PES and PES/chitosan membrane and chitosan characterization}

Addition of modifying agents always affects surface morphology of polymeric membranes. As such, surface images of the fabricated membrane were obtained with scanning electron microscopy (SEM), (TESCAN Vega 3xmu) equipped with EDS (OXFORD Xmas) to investigate morphological changes. The surface chemical structure of the membranes was analysed using Fourier transform infrared spectroscopy (FTIR). The wettability of the membranes was investigated using Dataphysics Optical contact angle analyser (OCA 15 EC GOP). The produced chitosan was characterised with Fourier transform infrared spectroscopy (FTIR) to identify functional groups present. The infrared spectra were recorded at room temperature in the wavenumber range of 4000 to $650 \mathrm{~cm}^{-1}$ using Perkin Elmer Spectrum. The particle size distribution of chitosan was determined using laser diffraction method (Malvern Mastersizer 2000 instrument).

\section{Porosity determination and contact angle analysis}

The overall membrane porosity was estimated gravimetrically using water swelling of the membrane via absorption as a criterion to obtain fractional free volume (porosity) within the membrane. Pieces of membranes were cut and immersed in distilled water for $24 \mathrm{~h}$ at room temperature. Then the wet membranes were taken and placed between two filter papers and weighed to achieve wet weight $\left(W_{w}\right)$. Thereafter, the wet membranes were placed in an oven at $50^{\circ} \mathrm{C}$ for $2 \mathrm{~h}$ and weighed again $\left(W_{d}\right)$. The bulk porosity was obtained using Eq. 5:

$$
\operatorname{Porosity}(\%)=\frac{W_{w}-W_{d}}{A \times l \times d_{w}} \times 100
$$

where $A$ is the membrane effective area, $l$ is the thickness measured with a digital micrometer and $d_{w}$ is water density $\left(0.998 \mathrm{~g} \cdot \mathrm{cm}^{-3}\right)$. Three pieces of membrane were measured, and the resultant average was taken as a final value.

The wettability of the membranes was investigated using Dataphysics Optical contact angle analyser (OCA 15 EC GOP) to quantify the hydrophilic properties of the membranes. Relatively 
low contact angle is an indication of the enhanced hydrophilic property of the membranes whereas high contact angle indicates a hydrophobic character. Ten random measurements were taken at different places on the membrane surface and the average value was utilized. It has been extensively reported that membrane-water contact angle keeps changing with time after water is dropped on the membrane surface. This was attributed to the evaporative effect. Therefore, as recommended by Bolong et al. (2009), to avoid this evaporative effect, measurements in this study were conducted as quickly as possible (within less than $10 \mathrm{~s}$ ).

\section{Membrane performance evaluation}

Membrane performance evaluation was conducted at room temperature using a dead-end filtration cell (Fig. 1) with a holding cell capacity of $300 \mathrm{~mL}$ and effective filtration area of $14.6 \mathrm{~cm}^{2}$. After the membrane was fixed, deionized water was passed through the membrane to pre-press and compact the membrane to ensure immersion of water. Pure water flux, $J,\left(\mathrm{~L} \cdot \mathrm{m}^{-2} \cdot \mathrm{h}^{-1}\right)$ was determined at ambient temperature by permeating deionized water through the membrane. Nitrogen was used as a pressuring gas during the tests. This was necessary to determine the initial/ original flux of the membrane before evaluating with AMD. The water flux was obtained using Eq. 6:

$$
J=\frac{V}{A t}
$$

where $V(\mathrm{~L})$ is the volume of permeated water, $A\left(\mathrm{~m}^{2}\right)$ is the effective membrane area and $t(\mathrm{~h})$ is the filtration time.

Synthetic AMD solution was fed through the filtration cell pressured with nitrogen gas to vary the feed pressure and filtrates were collected and analysed for metal ion content using atomic absorption spectroscopy (Thermo scientific ICE 3000 series). Sulphates were analysed using a UV-vis spectrophotometer following the United States Environmental Protection Agency Method 3754 (USEPA, 1983).

Metal ion rejection was determined using Eq. 7:

$$
R=\frac{C_{\text {feed }}-C_{\text {permeate }}}{C_{\text {feed }}} \times \frac{100}{1} \%
$$

where $R$ is the percentage rejection, $C_{\text {feed }}$ and $C_{\text {permeate }}\left(\mathrm{mg} \cdot \mathrm{L}^{-1}\right)$ are concentration of metal ion in the feed and permeate, respectively.

\section{RESULTS}

\section{Membrane characterization}

\section{Scanning electron microscopy}

Scanning electronic microscope images of both surface and cross-sections of the prepared membranes, used to evaluate the effect of chitosan concentration, are shown in Fig. 2. Since polymeric materials and membranes are nonconductive by nature, before mounting membrane samples onto the specimen they were exposed to carbon coating first. Additionally, before mounting them on the specimen, cross-section samples were quickly cryogenically fractured by hand after being immersed in liquid nitrogen for $10 \mathrm{~min}$ before carbon coating

The SEM images illustrated in Fig. 2 shed light on the surface morphology and surface porosity of the membranes and their corresponding cross-sectional view. The difference between PES membrane (Fig. 2(a)) and PES/chitosan membranes (Fig. 2(b-d) can be observed. Fig. 2(a) illustrates the surface morphology of PES support, with uniformly distributed pores. Comparing the images of PES/chitosan reveals a diminished number of

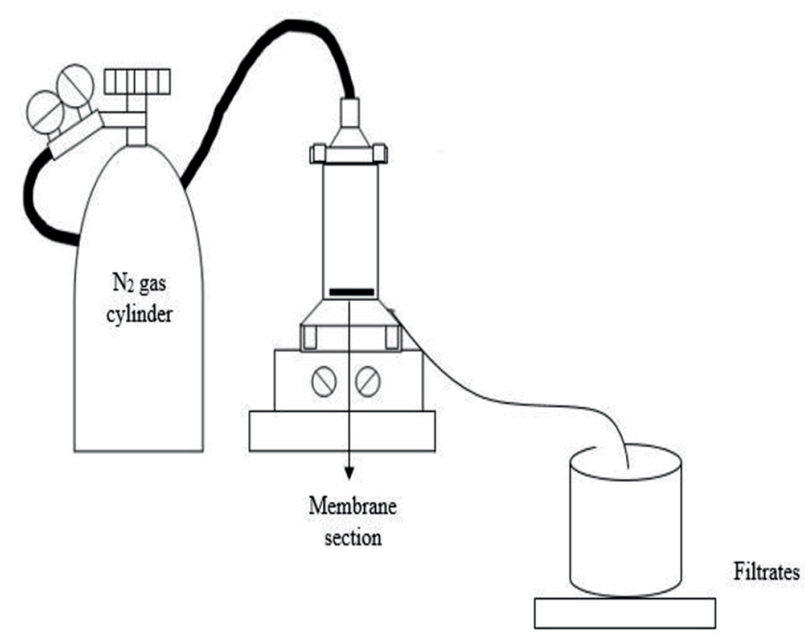

Figure 1. Dead-end filtration setup for performance evaluation

pores relative to the PES membrane. This is due to the addition of hydrophilic chitosan particles. The dense structure of PES/ chitosan is clearly seen in the SEM images. Increasing chitosan particles to 0.75 and $1 \mathrm{wt} \%$ resulted in a high viscous casting gel which reduced the rate of phase inversion and produced a denser and more compact membrane (Ghaemi et al., 2015).

During the phase inversion method, the cast film was immersed in a coagulation bath containing water. Therefore, hydrophilic membrane modifiers such as chitosan tend to accumulate on the membrane surface due to the high presence of hydroxyl and amino groups. The increasing hydrophilicity of the membrane is demonstrated by the water contact angle results for the membranes (Fig. 4). The contact angle of PES membrane reduced from $92^{\circ}$ to $64^{\circ}, 60^{\circ}$ and $58^{\circ}$ for PES $/ 0.5 \mathrm{wt} \%$ chitosan, $\mathrm{PES} / 0.75 \mathrm{wt} \%$ chitosan and $\mathrm{PES} / 1 \mathrm{wt} \%$ chitosan membranes, respectively. Figure 3 indicates the particle size distribution of chitosan particles which were synthesised from chitin; a mean size of $112 \mathrm{~nm}$ was observed. The membranes were cast on a glass plate using a hand casting knife set at $250 \mu \mathrm{m}$ thickness. The particle size distribution results show that the synthesized chitosan has acceptable dimensions to be added to the membrane without creating cracks within the membrane. The cross-section SEM images illustrate a typical asymmetric PES structure with a dense skin top layer and a porous sublayer with large pore wall thickness. Although surface morphology showed a denser surface after addition of chitosan, the cross-section images reveal a more porous sublayer and reduced pore wall thickness relative to unmodified PES membrane. Moreover, the skin layer thickness decreased with addition of chitosan particles up to $0.75 \mathrm{wt} \%$. Further addition to $1 \mathrm{wt} \%$ chitosan increased pore wall thickness and caused a reduction in membrane porosity (Table 2). Although unmodified PES membrane has bigger pores, its hydrophobic character is responsible for the low water flux. Increasing chitosan content from 0.5 to $0.75 \mathrm{wt} \%$ caused an increase in sub-layer micro-voids in the pore sizes from 2.2 to $4.11 \mu \mathrm{m}$. Further addition of chitosan to $1 \mathrm{wt} \%$ reduced the pores to $3.7 \mu \mathrm{m}$ and this justifies the decline in membrane permeability.

Table 2. Porosity and water permeability of the membranes

\begin{tabular}{lcc}
\hline Membrane & $\begin{array}{c}\text { Porosity } \\
(\%)\end{array}$ & $\begin{array}{c}\text { Water flux } \\
\left(\mathbf{L} \cdot \mathrm{m}^{-2} \cdot \mathbf{h}^{-1}\right)\end{array}$ \\
\hline PES & 47 & 102 \\
PES/0.5 wt\% chitosan & 70 & 107 \\
PES/0. 75wt\% chitosan & 66 & 133 \\
PES/1 wt\% chitosan & 41 & 120 \\
\hline
\end{tabular}




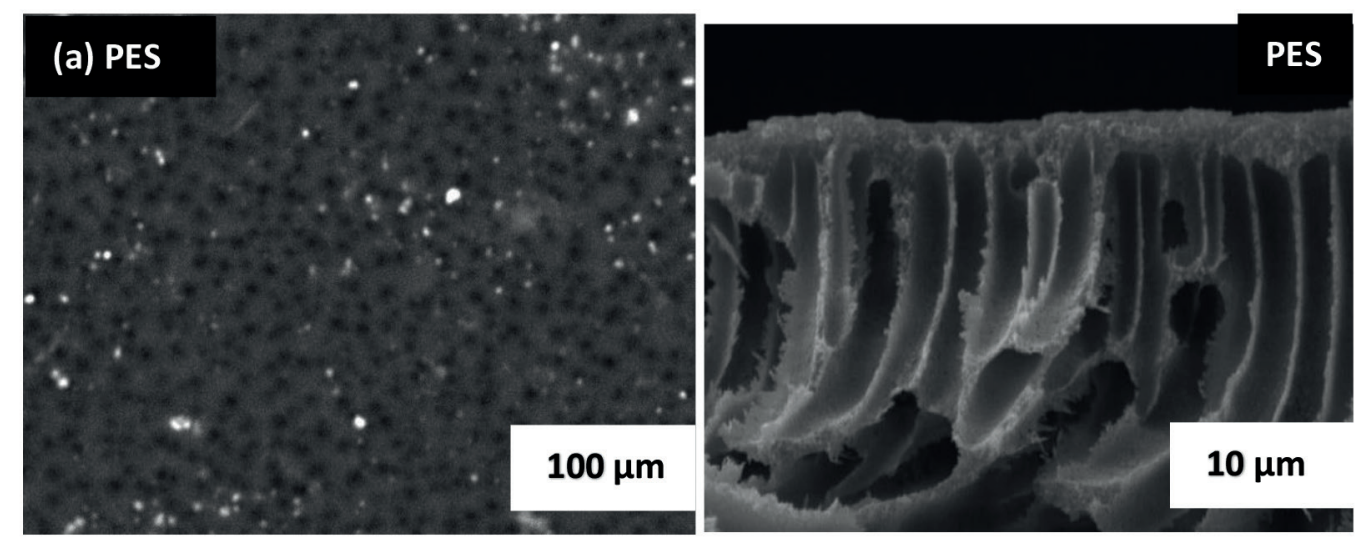

\section{(b) PES $/ 0.5 \%$ chitosan}
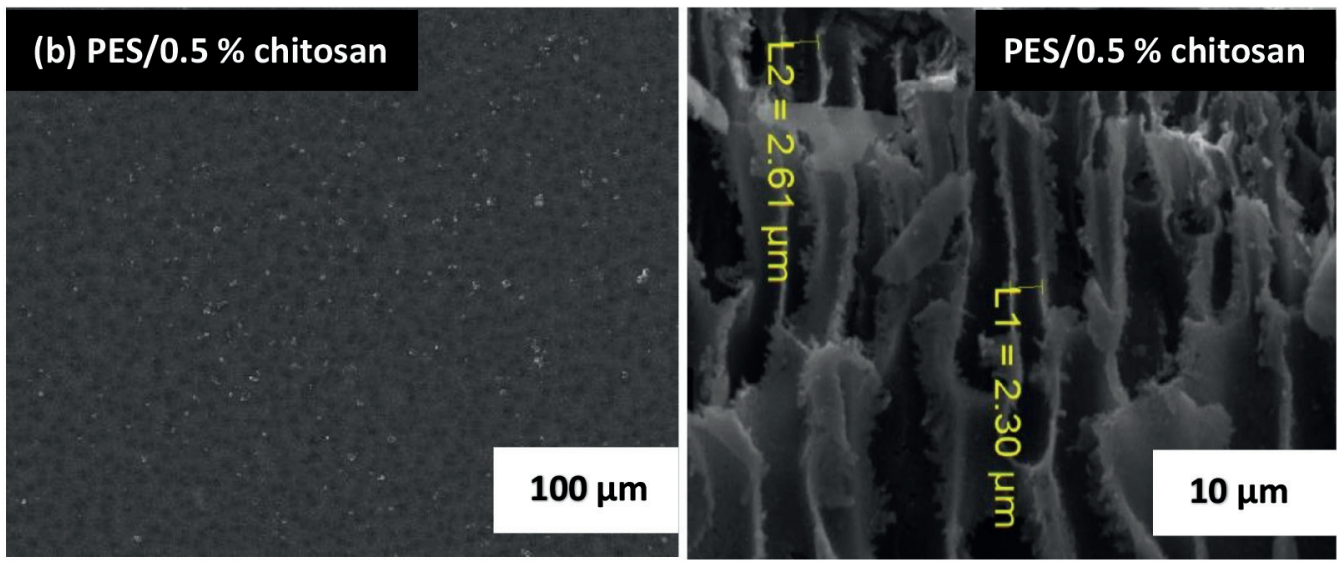

\section{(c) PES/0.75 \% chitosan}

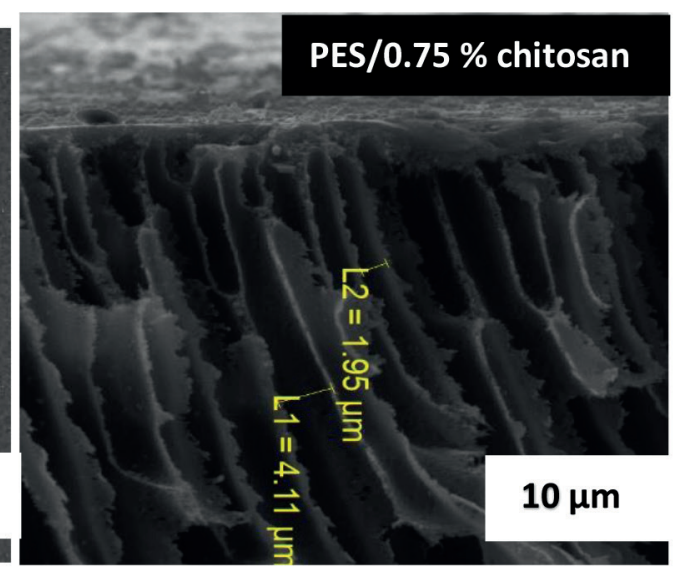

(d) PES/1 \% chitosan

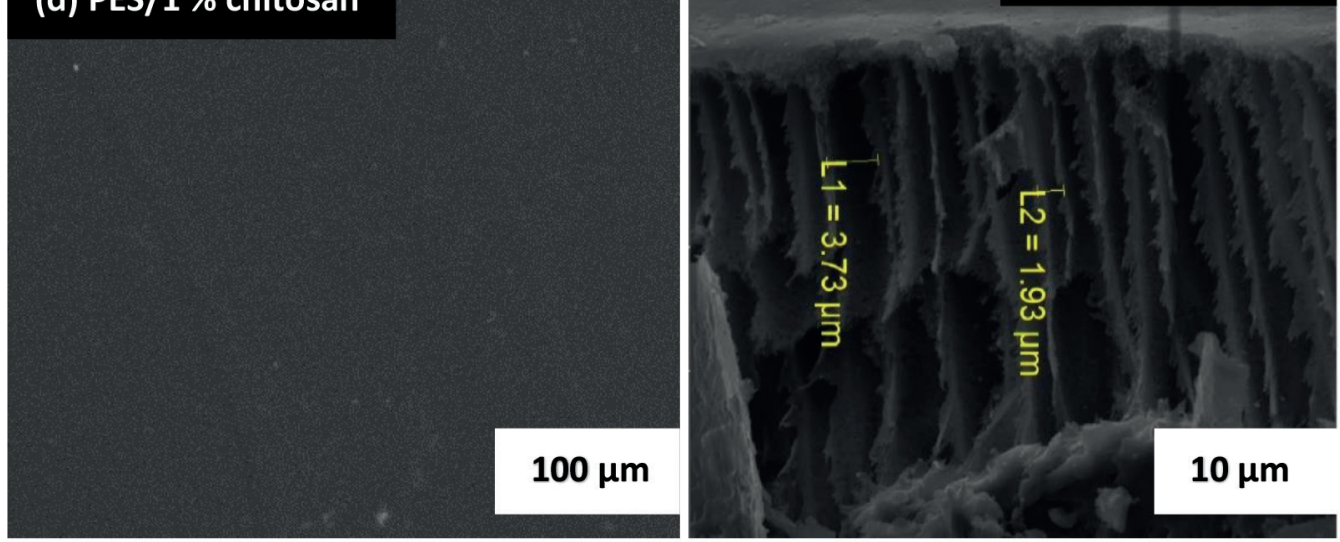

Figure 2. SEM micrographs of (a) PES, (b) PES/ 0.5 wt\% chitosan, (c) PES/0.75 wt\% chitosan and (d) PES/1 wt $\%$ chitosan membranes and corresponding cross-sectional view 


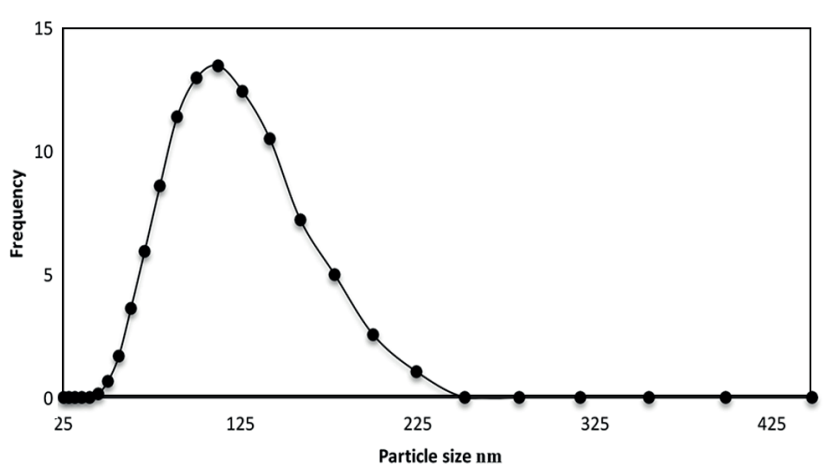

Figure 3. Particle size distribution of synthesised chitosan

\section{Fourier transform infrared}

Figure 4 compares the IR spectra of PES membranes blended with chitosan (Fig. 4a, 4b and 4c) with that of bare PES membrane (Fig. 4d) to verify structural information. The PES/ chitosan membranes were prepared by varying the chitosan concentration from 0.5 to $1 \%(\mathrm{w} / \mathrm{w})$. No significant differences between PES and PES/chitosan membranes could be perceived. However, flux and rejection experiments showed that the PES and PES/chitosan membrane performances were different. Although the PES and PES/chitosan membranes all had similar spectral peaks, SEM (Fig. 2) results showed reduced surface porous structure and enlarged macro-voids and pores with addition of chitosan. These spectral similarities could be attributed to the properties of the PES basic structure. Spectra

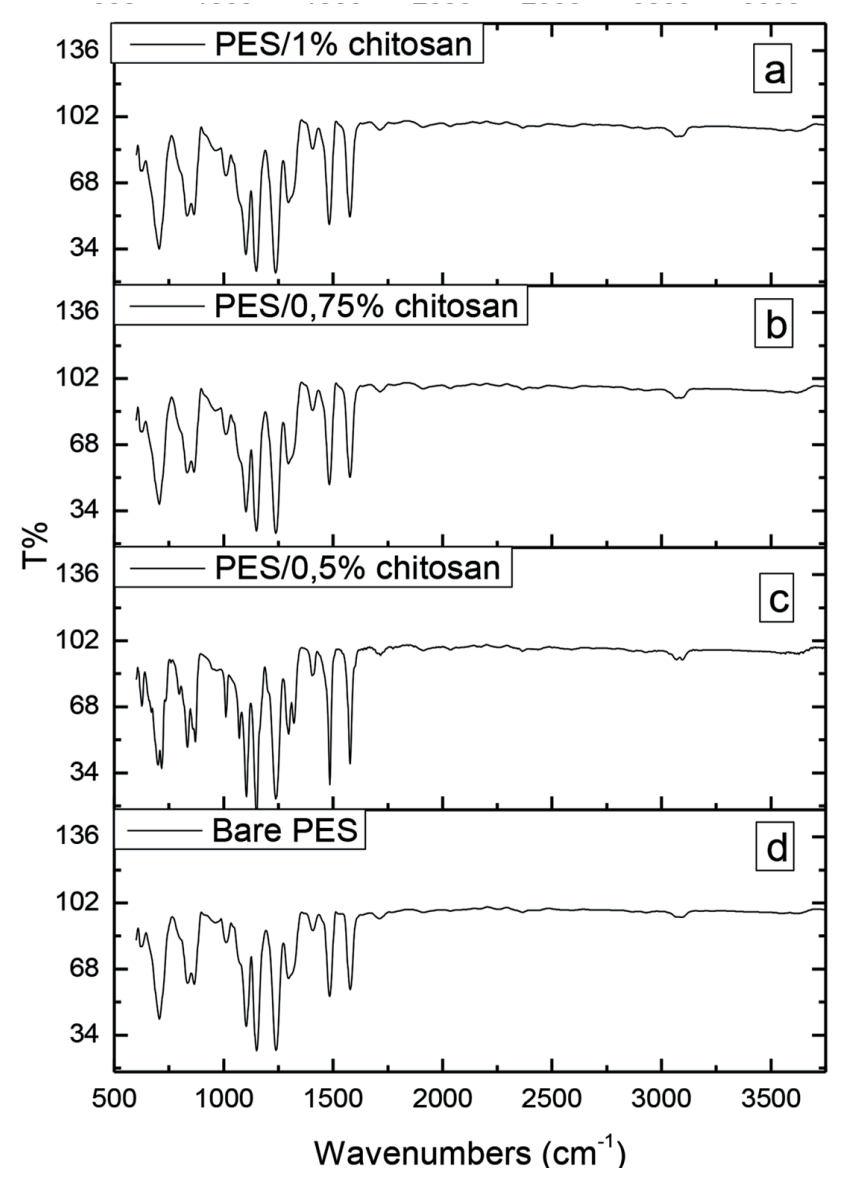

Figure 4. FTIR spectra of PES/1\% chitosan (a), PES/0.75\% chitosan (b), PES $/ 0.5 \%$ chitosan (c) and bare PES (d) of the PES sample were verified and are shown in Fig. $4 \mathrm{~d}$. The identified peak at $621 \mathrm{~cm}^{-1}$ is attributed to the C-stretching and $880 \mathrm{~cm}^{-1}$ to the $\mathrm{C}=\mathrm{C}$ stretching on the aromatic ring structure. The peaks at $1150 \mathrm{~cm}^{-1}, 1239 \mathrm{~cm}^{-1}$ and $1483 \mathrm{~cm}^{-1}$ could be attributed to the sulfonyl $(\mathrm{O}=\mathrm{S}=\mathrm{O})$ group while the aromatic ether (C-O-C) group is represented by the peak at $1296 \mathrm{~cm}^{-1}$. The sharp peak at $706 \mathrm{~cm}^{-1}$ indicates the C-S stretching. FTIR has been extensively used to characterize chemical composition on surface modification of PES-modified membranes (Zhao et al., 2013). PES chemical structure does not contain $\mathrm{O}-\mathrm{H}$ groups, however a typical $\mathrm{O}-\mathrm{H}$ stretching between 3200 and $3500 \mathrm{~cm}^{-1}$ was observed. The membrane was immersed in a coagulation bath containing deionized water to allow complete desorption, and heated in an oven at $60^{\circ} \mathrm{C}$ to evaporate any trapped water or solvent. It seemed that a small amount of water penetrated and remained within the porous structure. Similar conclusions have been reported in the literature (Belfer et al., 2000; Ghiggi et al., 2017).

\section{Contact angle analysis}

Figure 5 details the contact angle measurements of the membranes with varying chitosan content. Blending hydrophilic chitosan with PES membrane had a significant influence on the hydrophilicity of the membrane. It is clear that introduction of chitosan triggered a downward trend in contact angle. Addition of $0.5 \mathrm{wt} \%$ chitosan reduced the contact angle of the PES membrane from $92^{\circ}$ to $63.6^{\circ}$. Further addition of chitosan to $0.75 \mathrm{wt} \%$ and $1 \mathrm{wt} \%$ reduced the contact angle to $60.8^{\circ}$ and $58^{\circ}$, respectively. This reduction in contact angle could be explained by the enhancement of water transport through the membranes as a result of water molecules' interaction with the amide group of the hydrophilic chitosan through hydrogen bonding. This decrease in contact angle with increasing chitosan content affirms the influence of chitosan as an agent to enhance the membrane surface hydrophilicity. Although the membrane's hydrophilicity was increased by adding chitosan from 0 to $1 \mathrm{wt} \%$, as seen on Fig. 7, water flux of PES membranes at $1 \mathrm{wt} \%\left(97 \mathrm{~L} \cdot \mathrm{m}^{-2} \cdot \mathrm{h}^{-1}\right)$ chitosan content was lower than that at $0.75 \mathrm{wt} \%\left(121 \mathrm{~L} \cdot \mathrm{m}^{-2} \cdot \mathrm{h}^{-1}\right)$. Membrane permeability is affected considerably by membrane porosity, hydrophilicity and surface roughness. The increase in chitosan content from 0.75 to $1 \mathrm{wt} \%$ resulted in a decrease in the effective pore size (fractional free volume) of the membrane, which reduced the porosity of the membrane. Furthermore, introducing chitosan as an additional hydrophilic agent improved the degree of hydrophilicity of the membranes as compared to the study conducted by Shockravi et al. (2017). Introduction of chitosan improved the degree of hydrophilicity of the membrane by $58 \%$.

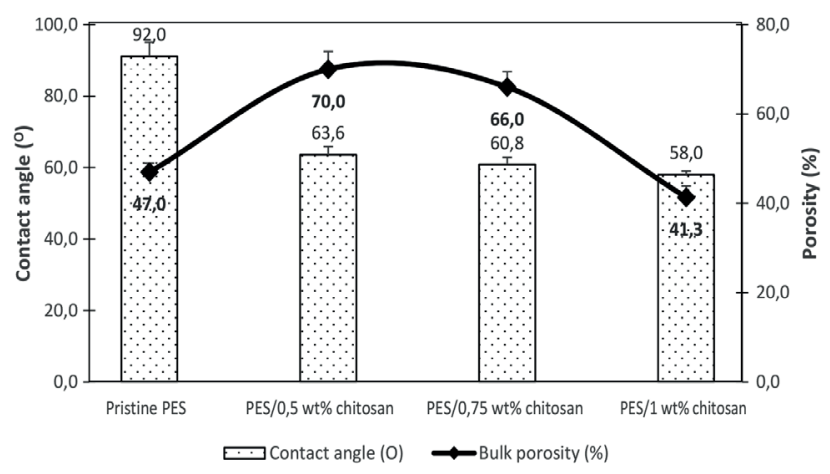

Figure 5. Static water contact angle and bulk porosity of the membranes 


\section{Membrane performance investigation}

\section{Membrane initial/original membrane flux}

Figures 6 and 7 demonstrate initial water flux of the membrane against various chitosan concentrations $(0,0.5,0.75$ and $1 \mathrm{wt} \%)$. Table 2 provides information about the relation between the membrane porosity and the PWF. The membranes were pre-pressed with deionized water to ensure complete immersion of water in the membranes before analysis. The operating pressure was increased at an interval of 1 bar $\left(10^{5} \mathrm{~N} \cdot \mathrm{m}^{-2}\right)$ (Fig. 6). When the pressure was increased from 4 bar to 5 bar $\left(4 \times 10^{5} \mathrm{~N} \cdot \mathrm{m}^{-2}\right.$ to $\left.5 \times 10^{5} \mathrm{~N} \cdot \mathrm{m}^{-2}\right)$, the membrane was ripped apart. This is because increasing the applied pressure across the membrane is associated with large shear stress forces which push water molecules through the membrane wall surface. Under high pressure, more wastewater will be treated in a shorter period with contaminants pushed through the membrane surface. Conversely, low applied pressure will result in reduced transmembrane pressure which may lead to accumulation of particles on the membrane surface wall, as necessitated by laminar flow (Cheng and Lin, 2004). It would be expected that high pressures will force adsorbed materials on the membrane surface to permeate through the membrane and reduce rejection. Contrary to this, studies have proven that increasing transmembrane pressure in nanofiltration and reverse osmosis membrane application promotes sorption of water molecules and eventually results in an increase in water flux through the membrane (Zhong et al., 2007). Consequently, separation tests were conducted at 4 bar to ensure maximum membrane flux during the tests.

Figure 7 illustrates the effect of chitosan concentration on permeate flux of the membranes at 4 bars when filtering AMD solution. Addition of $0.5 \mathrm{wt} \%$ of chitosan particles induced an increment in pure water flux (PWF) from 97 to $108 \mathrm{~L} \cdot \mathrm{m}^{-2} \cdot \mathrm{h}^{-1}$. When chitosan concentration was increased to $0.75 \mathrm{wt} \%$, the PWF reached its highest value of $121 \mathrm{~L} \cdot \mathrm{m}^{-2} \cdot \mathrm{h}^{-1}$, which is about $20 \%$ more than the unmodified membrane. However, increasing the chitosan amount in the blend to $1 \mathrm{wt} \%$ caused a water flux decline to $116 \mathrm{~L} \cdot \mathrm{m}^{-2} \cdot \mathrm{h}^{-1}$, though the flux was still higher than that of PES membrane. This could be attributed to the fact that increasing the chitosan amount caused blockage of effective pore sizes of the membrane. Chitosan is more hydrophilic than PES membrane due to its numerous functional groups which favour sorption of water molecules on the membrane surface; hence increased water flux was realised with increasing chitosan concentration. As mentioned earlier, membrane porosity and hydrophilicity play a vital role in membrane permeability; the results show that membrane permeability was influenced positively by the hydrophilic nature of the membrane when chitosan amount was $0.75 \mathrm{wt} \%$. As observed in Fig. 5, though the hydrophilicity of the membrane increased with addition of chitosan to $1 \mathrm{wt} \%$, its bulk porosity declined to $66.0 \%$, showing that porosity dominated and influenced permeability and hence the flux declined. Chitosan is a hydrophilic filler and its addition should enhance the hydrophilicity of the membrane, which was observed at the loading of $5 \mathrm{wt} \%$ and $0.75 \mathrm{wt} \%$. However, when the loading was increased to $1 \mathrm{wt} \%$ the degree of hydrophilicity reduced (see Fig. 7). This indicates that optimal loading is necessary to achieve an optimal degree of hydrophilicity.

The membranes were modified with different amounts of chitosan $(0,0.5,0.75$ and $1 \mathrm{wt} \%)$ and Fig. 8 illustrates the rejection of selected constituents in the synthetic AMD. The feed and permeate temperature did not differ significantly, therefore, the effect of temperature on membrane performance was ignored. The observed trend showed that addition of chitosan into the PES membrane matrix improved metal ion rejection. Additionally, the rejection of cations $\left(\mathrm{Fe}^{2+}, \mathrm{Mn}^{2+}, \mathrm{Mg}^{2+}\right.$ and $\left.\mathrm{Ca}^{2+}\right)$ was higher than the rejection of anions $\left(\mathrm{SO}_{4}^{2-}\right)$. In membrane separation processes, not only does the filtration mechanism exhibit a rejection process, but membrane surface charge also plays a vital role. It is generally known that PES membranes exhibit negatively charged surfaces without chitosan; therefore, rejection of anions was due to repulsive forces between anions and the negatively charged membrane through the Donnan exclusion mechanism (Crespo et al., 2014). As such, cation removal was due to ion exchange with the negatively charged surface of the PES membrane.

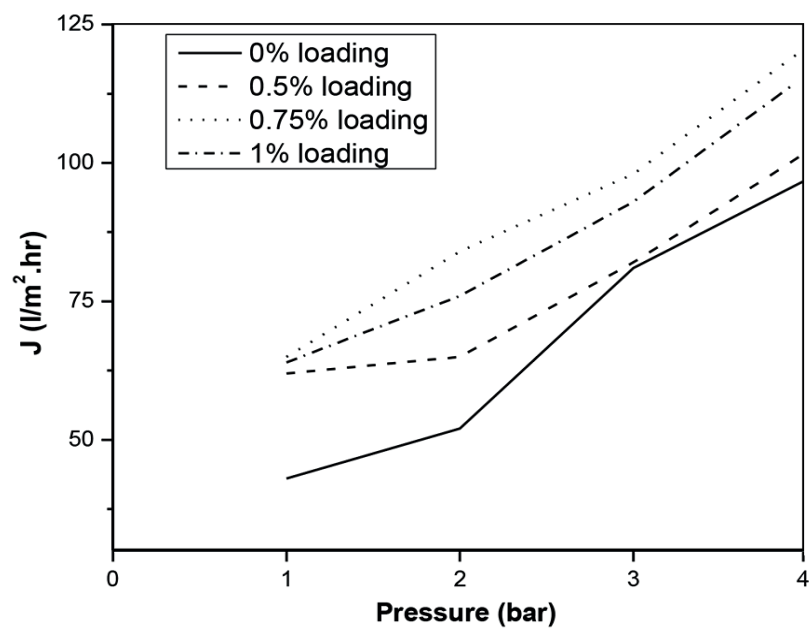

Figure 6. The effect of operating pressure on membrane flux at room temperature

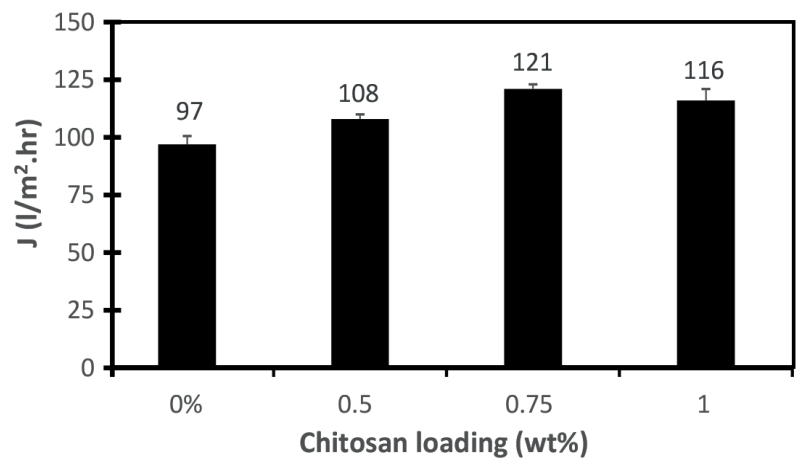

Figure 7. Effect of chitosan on membrane flux of PES/chitosan membranes

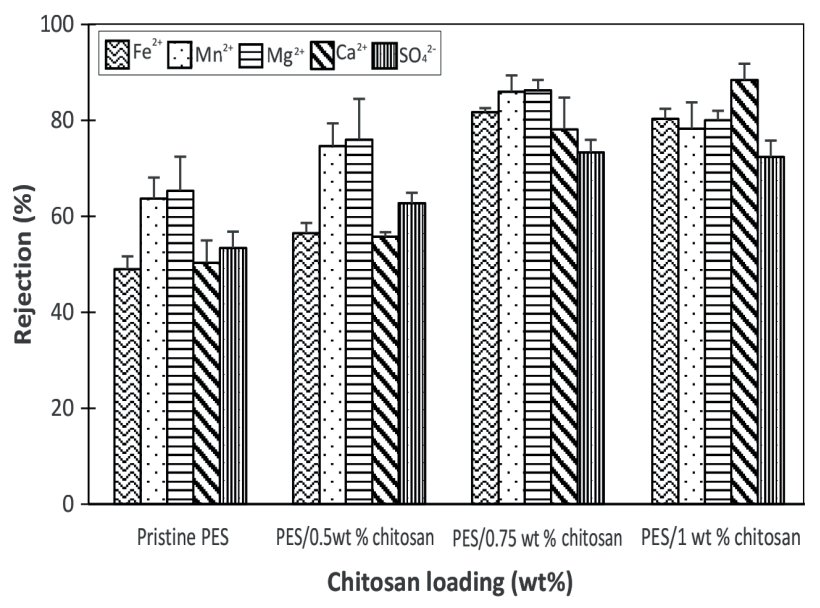

Figure 8. Rejection (\%) of metal and sulphate ions using PES and PES/ chitosan membranes 
The $\mathrm{pH}$ of the feed used in this test was 3.2. Consequently, the higher rejection of cations $\left(\mathrm{Mn}^{2+}, \mathrm{Fe}^{2+}, \mathrm{Mg}^{2+}\right.$ and $\left.\mathrm{Ca}^{2+}\right)$ as compared to anions $\left(\mathrm{SO}_{4}{ }^{2-}\right)$ could be attributed to the dominance of the strong repulsive forces between the positively charged membranes and the metal ions. In acidic solutions, the amine groups on the chitosan attract protons to form quaternary amine groups which cause the membrane to be more positively charged. Cation removal would be due to the electrostatic repulsive forces generated by the positive membrane and the cations. Additionally, sulphate ion removal will be attributed to the electrostatic attraction between the positive membrane and the anions.

Amine groups on the chitosan structure remain uncharged at neutral $\mathrm{pH}$ and addition of chitosan into the PES membrane matrix cannot affect the surface charge of the PES membrane. However, filtration tests in this study were conducted at a $\mathrm{pH}$ of 3.2, which protonates amine groups on chitosan (Liu et al., 2013). It could be observed that anion rejection improved from $53 \%$ for pristine PES membrane to 62,73 and $72 \%$ for $\mathrm{PES} / 0.5 \mathrm{wt} \%, \mathrm{PES} / 0.75 \mathrm{wt} \%$ and $\mathrm{PES} / 1 \mathrm{wt} \%$, respectively. This improvement in the rejection of sulphate ions by modified PES membrane could be attributed to adsorption of sulphate ions by the positively charged sites created on the chitosan structure under acidic conditions. In addition to the membrane's sieving mechanism, the strong cation removal behaviour was also due to strong dominant electrostatic repulsive forces between the positively charged membrane surface and cations. Metal ion rejection by the pristine PES membranes was $52 \%\left(\mathrm{Fe}^{2+}\right)$, $63 \%\left(\mathrm{Mn}^{2+}\right), 65 \%\left(\mathrm{Mg}^{2+}\right)$ and $50 \%\left(\mathrm{Ca}^{2+}\right)$. Adding $0.5 \mathrm{wt} \%$ chitosan to the PES blend improved membrane rejection to $56 \%, 74 \%, 76 \%$ and $55 \%$ for $\mathrm{Fe}^{2+}, \mathrm{Mn}^{2+}, \mathrm{Mg}^{2+}, \mathrm{Ca}^{2+}$, respectively. The general observed trend is that rejection increased with increasing chitosan content from 0 to $0.75 \mathrm{wt} \%$. This was due to introduction of more amine functional groups which when protonated repel the cations or attract anions. It is reported in literature that metal ions favour formation of metal complexes with $\mathrm{OH}^{-}$groups at higher $\mathrm{pH}$, and membrane rejection favours metal complexes rather than metal ions (Al-Zoubi et al., 2010). As recorded earlier, $\mathrm{pH}$ of the feed solution was acidic; therefore it could be concluded that the cations were removed as metal ions. Furthermore, introducing more chitosan particles to $1 \mathrm{wt} \%$ reduced membrane flux and rejection. This could be caused by molecular entanglement and aggregation which forms a thick layer of chitosan and creates weaker pore walls with bigger pore sizes. This pore size enlargement creates free passage for the contaminants and leads to lower rejection. Table 3 presents a comparison of pristine PES membranes and PES membrane modified with chitosan and multi-walled carbon nanotubes for treatment of wastewater containing metals, salts and oil. The PES membrane modified with multiwalled carbon nanotubes (MWCNTs) was added to compare a different modifier. Additionally, oil- and salt-containing wastewater are also considered to enable comparison with a different contaminant to AMD.

\section{CONCLUSION}

In this study, polyethersulphone (PES) membrane was modified by introducing chitosan particles and tested for acid mine drainage treatment. The resulting membranes displayed improved pure water flux from $102 \mathrm{~L} \cdot \mathrm{m}^{-2} \cdot \mathrm{h}^{-1}$ for pristine PES membrane to $107 \mathrm{~L} \cdot \mathrm{m}^{-2} \cdot \mathrm{h}^{-1}$ and $133 \mathrm{~L} \cdot \mathrm{m}^{-2} \cdot \mathrm{h}^{-1}$ for PES $/ 0.5 \mathrm{wt} \%$ and PES/ $0.75 \mathrm{wt} \%$, respectively. Further chitosan addition to $1 \mathrm{wt} \%$ created a dense structure (as observed on SEM images) which had a negative effect on permeability, which reduce the pure water flux to $120 \mathrm{~L} \cdot \mathrm{m}^{-2} \cdot \mathrm{h}^{-1}$. An improved degree of hydrophilicity with the addition of chitosan as a hydrophilic agent was confirmed by contact angle analysis which revealed a downward trend with increasing chitosan content. The observed high cation rejection relative to anions affirmed strong electrostatic repulsion by the membrane. However, further investigations aimed at enhancing performance, and checking operational stability and antifouling properties of the membrane during AMD treatment are required. Nevertheless, the results reported in this study reveal potential application of PES membrane modified with chitosan in the treatment of AMD.

\section{ACKNOWLEDGEMENTS}

The authors would like to acknowledge the CHMT of Wits University and University of Johannesburg for providing resources required to fulfil the objectives of the study. The effort by colleagues who assisted with characterization and analysis of the membranes is highly appreciated. The work was supported financially by the National Research Foundation of South Africa.

\section{REFERENCES}

AGUIAR AO, ANDRADE LH, RICCI BC, PIRES WL, MIRANDA GA and AMARAL MC (2016) Gold acid mine drainage treatment by membrane separation processes: An evaluation of the main operational conditions. Sep. Purif. Technol. $170360-369$. https://doi. org/10.1016/j.seppur.2016.07.003

AL-ZOUBI H, RIEGER A, STEINBERGER P, PELZ W, HASENEDER R and HÄRTEL G (2010) Optimization study for treatment of acid mine drainage using membrane technology. Sep. Sci. Technol. 45 (14) 2004-2016. https://doi.org/10.1080/01496395.2010.480963

ANIRUDHAN TS and RIJITH S (2012) Synthesis and characterization

Table 3. Comparison of membrane performance with other studies in literature

\begin{tabular}{|c|c|c|c|}
\hline Membrane & Target contaminant & Outcomes & References \\
\hline PES membrane & $\mathrm{Fe}^{2+}, \mathrm{Na}^{+}, \mathrm{Mn}^{2+}, \mathrm{Mg}^{2+}, \mathrm{SO}_{4}{ }^{2-}, \mathrm{Cl}^{-}$ & $\begin{array}{l}\text { Flux range: } 3 \text { to } 3.45 \mathrm{~L} \cdot \mathrm{m}^{-2} \cdot \mathrm{h}^{-1} \\
\text { Overall maximum rejection was } 61 \%\end{array}$ & Mthethwa, 2014 \\
\hline PES & Oil refinery wastewater (COD, OGC) & $\begin{array}{l}\text { Maximum of } 84 \mathrm{~L} \cdot \mathrm{m}^{-2} \cdot \mathrm{h}^{-1} \\
\text { Rejection of at } 83.1 \% \text { COD, } 99.7 \% \text { OGC }\end{array}$ & Salahi et al., 2015 \\
\hline PES/MWCNTs & $\mathrm{Na}_{2} \mathrm{SO}_{4^{\prime}} \mathrm{NaCl}, \mathrm{MgSO}_{4}$ & $\begin{array}{l}\text { Maximum flux of about } 14 \mathrm{~L} \cdot \mathrm{m}^{-2} \cdot \mathrm{h}^{-1} \\
\text { Up to } 89 \% \text { rejection }\end{array}$ & Vatanpour et al., 2012 \\
\hline PES/chitosan membrane & $\mathrm{NO}_{3}^{-}$ & $\begin{array}{l}\text { Maximum flux of } 18 \mathrm{~L} \cdot \mathrm{m}^{-2} \cdot \mathrm{h}^{-1} \\
\text { Rejection of } \pm 96 \%\end{array}$ & Ghaemi et al., 2018 \\
\hline PES/chitosan membrane & $\begin{array}{l}\mathrm{NaCl}, \mathrm{Na}_{2} \mathrm{SO}_{4} \\
\mathrm{HgCl} \text { and } \mathrm{HgSO}_{4}\end{array}$ & $\begin{array}{l}\text { Flux of } \pm 150 \mathrm{~L} \cdot \mathrm{m}^{-2} \cdot \mathrm{h}^{-1} \text { for } \mathrm{NaCl} \text { and } \mathrm{HgCl} \text { solution } \\
\text { and } 140 \mathrm{~L} \cdot \mathrm{m}^{-2} \cdot \mathrm{h}^{-1} \text { for } \mathrm{Na}_{2} \mathrm{SO}_{4} \text { solution. } \\
\text { Rejection of } \mathrm{NaCl} \text { and } \mathrm{Na}_{2} \mathrm{SO}_{4} \text { at } \pm 28 \text { and } 60 \% \text {. } \\
\text { Rejection of } \mathrm{HgCl} \text { and } \mathrm{HgSO}_{4} \text { at } \pm 45 \text { and } 70 \%\end{array}$ & Boricha and Murthy, 2009 \\
\hline PES/chitosan membrane & $\mathrm{Fe}^{2+}, \mathrm{Ca}^{2+}, \mathrm{Mn}^{2+}, \mathrm{Mg}^{2+}$, and $\mathrm{SO}_{4}^{2-}$ & $\begin{array}{l}\text { Maximum flux of } 133 \mathrm{~L} \cdot \mathrm{m}^{-2} \cdot \mathrm{h}^{-1} \\
\text { Cation rejection of } 89 \% \text { and } 72 \% \text { for sulphate ions }\end{array}$ & This study \\
\hline
\end{tabular}


of carboxyl terminated poly (methacrylic acid) grafted chitosan/ bentonite composite and its application for the recovery of uranium (VI) from aqueous media. J. Environ. Radioactivity 106 8-19. https:// doi.org/10.1016/j.jenvrad.2011.10.013

BELFER S, FAINCHTAIN R, PURINSON $\mathrm{Y}$ and KEDEM O (2000) Surface characterization by FTIR-ATR spectroscopy of polyethersulfone membranes-unmodified, modified and protein fouled. J. Membr. Sci. 172 (1) 113-124. https://doi.org/10.1016/ S0376-7388(00)00316-1

BOLONG N, ISMAIL AF, SALIM MR, RANA D and MATSUURA T (2009) Development and characterization of novel charged surface modification macromolecule to polyethersulfone hollow fiber membrane with polyvinylpyrrolidone and water. J. Membr. Sci. 331 (1-2) 40-49. https://doi.org/10.1016/j.memsci.2009.01.008

BORICHA AG and MURTHY ZVP (2009) Acrylonitrile butadiene styrene/chitosan blend membranes: Preparation, characterization and performance for the separation of heavy metals. J. Membr. Sci. 339 (1-2) 239-249. https://doi.org/10.1016/j.memsci.2009.04.057

BWAPWA JK, JAIYEOLA AT and CHETTY R (2017) Bioremediation of acid mine drainage using algae strains: A review. S. Afr. J. Chem. Eng. 24 62-70. https://doi.org/10.1016/j.sajce.2017.06.005

CARVALHO AL, MAUGERI F, PRADANOS P, SILVA $V$ and HERNANDEZ A (2011) Separation of potassium clavulanate and potassium chloride by nanofiltration: Transport and evaluation of membranes. Sep. Purif. Technol. 83 23-30. https://doi.org/10.1016/j. seppur.2011.07.019

CHENG TW and LIN CT (2004) A study on cross-flow ultrafiltration with various membrane orientations. Sep. Purif. Technol. 39 (1-2) 13-22. https://doi.org/10.1016/j.seppur.2003.12.008

CRESPO GA, AFSHAR MG and BAKKER E (2014) Chronopotentiometry of pure electrolytes with anion-exchange donnan exclusion membranes. J. Electroanal. Chem. 731 100-106. https://doi.org/10.1016/j.jelechem.2014.08.007

DARAMOLA MO, SILINDA B, MASONDO $S$ and OLUWASINA OO (2015) Polyethersulphone-sodalite (PES-SOD) mixed-matrix membranes: Prospects for acid mine drainage (AMD) treatment J. South. Afr. Inst. Min. Met. 115 (12) 1221-1228. https://doi. org/10.17159/2411-9717/2015/v115n12a11

ELIMELECH M and PHILLIP WA (2011) The future of seawater desalination: energy, technology, and the environment. Science 333 (6043) 712-717. https://doi.org/10.1126/science.1200488

GEISE GM, LEE, HS, MILLER DJ, FREEMAN BD, MCGRATH JE and PAUL DR (2010) Water purification by membranes: the role of polymer science. J. Polym. Sci. Part B: Polym. Phys. 48 (15) 1685 1718. https://doi.org/10.1002/polb.22037

GHAEMI N, DARAEI P and AKHLAGHI FS (2018) Polyethersulfone nanofiltration membrane embedded by chitosan nanoparticles: Fabrication, characterization and performance in nitrate removal from water. Carbohydrate Polym. 191 142-151. https://doi. org/10.1016/j.carbpol.2018.03.024

GHAEMI N, MADAENI SS, DARAEI P, RAJABI H, ZINADINI S ALIZADEH A, HEYDARI R, BEYGZADEH M and GHOUZIVAND $S$ (2015) Polyethersulfone membrane enhanced with iron oxide nanoparticles for copper removal from water: application of new functionalized Fe3O4 nanoparticles. Chem. Eng. J. 263 101-112. https://doi.org/10.1016/j.cej.2014.10.103

GHIGGI FF, POLLO LD, CARDOZO NS and TESSARO IC (2017) Preparation and characterization of polyethersulfone/N-phthaloylchitosan ultrafiltration membrane with antifouling property. Eur. Polym. J. 92 61-70. https://doi.org/10.1016/j.eurpolymj.2017.04.030

JI J, WU D, CAO Z, DENG L and YUN Y (2015) Preparation and evaluation of poly (phthalazinone ether sulfone ketone) ultrafiltration membrane with organic and inorganic nano-TiO2 additives. J. Sol-Gel Sci. Technol. 76 (2) 446-455. https://doi. org/10.1007/s10971-015-3793-2

KAUR G, COUPERTHWAITE SJ, HATTON-JONES BW and MILLAR GJ (2018) Alternative neutralisation materials for acid mine drainage treatment. J. Water Process Eng. 22 46-58. https://doi.org/10.1016/j. jwpe.2018.01.004

KEFENI KK, MSAGATI TA, NKAMBULE TT and MAMBA BB (2018) Synthesis and application of hematite nanoparticles for acid mine drainage treatment. J. Environ. Chem. Eng. 6 (2) 1865-1874. https:// doi.org/10.1016/j.jece.2018.02.037
KHULBE KC, FENG C and MATSUURA T (2010) The art of surface modification of synthetic polymeric membranes. J. Appl. Polym. Sci. 115 (2) 855-895. https://doi.org/10.1002/app.31108

LARSSON M, NOSRATI A, KAUR S, WAGNER J, BAUS U and NYDÉN M (2018) Copper removal from acid mine drainage-polluted water using glutaraldehyde-polyethyleneimine modified diatomaceous earth particles. Heliyon 4 (2) e00520. https://doi.org/10.1016/j. heliyon.2018.e00520

LIU B, WANG D, YU G and MENG X (2013) Adsorption of heavy metal ions, dyes and proteins by chitosan composites and derivatives-A review. J. Ocean Univ. China 12 (3) 500-508. https://doi.org/10.1007/ s11802-013-2113-0

MTHETHWA V (2014) Investigation of polyethersulfone (PES) hollow fiber membrane for the treatment of acid mine drainage. Research Report, MSc. Eng., University of the Witwatersrand.

OTHMAN A, SULAIMAN A and SULAIMAN SK (2017) Carbide lime in acid mine drainage treatment. J. Water Process Eng. 15 31-36. https://doi.org/10.1016/j.jwpe.2016.06.006

PEYRAVI M, RAHIMPOUR A, JAHANSHAHI M, JAVADI A and SHOCKRAVI A (2012) Tailoring the surface properties of PES ultrafiltration membranes to reduce the fouling resistance using synthesized hydrophilic copolymer. Micropor. Mesopor. Mater. 160 114-125. https://doi.org/10.1016/j.micromeso.2012.04.036

RAHIMPOUR A (2011) UV photo-grafting of hydrophilic monomers onto the surface of nano-porous PES membranes for improving surface properties. Desalination 265 (1) 93-101. https://doi. org/10.1016/j.desal.2010.07.037

REDDY AVR, MOHAN DJ, BHATTACHARYA A, SHAH V and GHOSH PK (2003) Surface modification of ultrafiltration membranes by preadsorption of a negatively charged polymer: I. Permeation of water soluble polymers and inorganic salt solutions and fouling resistance properties. J. Membr. Sci. 214 (2) 211-221. https://doi.org/10.1016/S0376-7388(02)00547-1

RITCHIE SMC and BHATTACHARYYA D (2002) Membrane-based hybrid processes for high water recovery and selective inorganic pollutant separation. J. Hazardous Mater. 92 (1) 21-32. https://doi. org/10.1016/S0304-3894(01)00370-3

SALAHI A, MOHAMMADI T, BEHBAHANI RM and HEMMATI M (2015) Asymmetric polyethersulfone ultrafiltration membranes for oily wastewater treatment: synthesis, characterization, ANFIS modeling, and performance. J. Environ. Chem. Eng. 3 (1) 170-178. https://doi.org/10.1016/j.jece.2014.10.021

SHOCKRAVI A, VATANPOUR V, NAJJAR Z, BAHADORI S and JAVADI A (2017) A new high-performance polyamide as an effective additive for modification of antifouling properties and morphology of asymmetric PES blend ultrafiltration membranes. Micropor. Mesopor. Mater. 246 24-36. https://doi.org/10.1016/j. micromeso.2017.03.013

TUTU H, MCCARTHY TS and CUKROWSKA E (2008) The Chemical Characteristics of Acid Mine Drainage with Particular Reference to Sources, Distribution and Remediation: The Witwatersrand Basin, South Africa as a Case Study. Appl. Geochem. 23 (12) 3666-3684. https://doi.org/10.1016/j.apgeochem.2008.09.002

USEPA (United States Environmental Protection Agency) (1983) Methods for Chemical Analysis of Water and Waste EPA-600/4-79020 Method 375.4. OffIce of Research and Development, USEPA, Washington, DC

VAN DER BRUGGEN B (2009) Chemical modification of polyethersulphone nanofiltration membranes: a review. J. Appl. Polym. Sci. 114 (1) 630-642. https://doi.org/10.1002/app.30578

VATANPOUR V, MADAENISS, KHATAEE AR, SALEHIE, ZINADINI $S$ and MONFARED HA (2012) $\mathrm{TiO}_{2}$ embedded mixed matrix PES nanocomposite membranes: influence of different sizes and types of nanoparticles on antifouling and performance. Desalination 292 19-29. https://doi.org/10.1016/j.desal.2012.02.006

WAN NGAHA WS, TEONGA LC and HANAFIAH MAKM (2011) Adsorption of dyes and heavy metal ions by chitosan composites: A review: Carbohydrate Polym. 83 1446-1456. https://doi.org/10.1016/j. carbpol.2010.11.004

WEI X, WANG Z, FAN F, WANG J and WANG S (2010) Advanced treatment of a complex pharmaceutical wastewater by nanofiltration: membrane foulant identification and cleaning. Desalination 251 (1) 167-175. https://doi.org/10.1016/j.desal.2009.08.005 
ZHAO C, XUE J, RAN F and SUN S (2013) Modification of polyethersulphone membranes - a review of methods. Prog. Mater. Sci. 58 (1) 76-150. https://doi.org/10.1016/j.pmatsci.2012.07.002 ZHONG CM, XU ZL, FANG XH and CHENG L (2007) Treatment of acid mine drainage (AMD) by ultra-low-pressure reverse osmosis and nanofiltration. Environ. Eng. Sci. 24 (9) 1297-1306. https://doi. org/10.1016/j.pmatsci.2012.07.002 